\title{
Study of association between hypovitminosis D and fibroid uterus
}

\author{
Sangeeta Choudhary, Mala Shukla, Ruchi Joshi*
}

Department of Obstetrics and Gynecology, NDMC and Hindu Rao Hospital, Delhi, India

Received: 21 March 2021

Revised: 09 May 2021

Accepted: 10 May 2021

\section{*Correspondence:}

Dr. Ruchi Joshi,

E-mail: sensibleruchi@gmail.com

Copyright: (C) the author(s), publisher and licensee Medip Academy. This is an open-access article distributed under the terms of the Creative Commons Attribution Non-Commercial License, which permits unrestricted non-commercial use, distribution, and reproduction in any medium, provided the original work is properly cited.

\section{ABSTRACT}

Background: Fibroid uterus or leiomyoma is a benign tumour composed mainly of unicellular smooth muscle cells with varying amounts of fibrous connective tissue. UF are associated with significant morbidity as it presents in form of abnormal uterine bleeding, anaemia, pelvic pain, subfertility, and obstetric complications and causes financial burden on the patient. Recent studies have shown the critical role that vitamin D plays in fibroid formation, with individual fibroids expressing lower levels of vitamin D receptors than adjacent healthy tissue, making vitamin D deficiency a crucial, yet preventable risk factor.

Methods: This was cross-sectional observational study. It was conducted on 140 female patients aged (18 to 50 years) presenting to the OPD of department of obstetrics and gynecology at NDMC \& Hindu Rao Hospital during July 2019 to June 2020. 70 women had uterine fibroids on ultrasound and treated as cases and rest healthy women without fibroids served as controls. All women were subjected to ultrasound examination of uterus followed by serum vitamin D3 levels. Results: The mean value of vitamin D levels in cases was $12.81 \pm 8.56 \mathrm{ng} / \mathrm{ml}$ and in controls it was $19.83 \pm 9.21 \mathrm{ng} / \mathrm{ml}$ with $\mathrm{p}$ value $<0.0001$. Thus, it was statistically significant lower in cases of fibroid uterus as compared to controls. Secondary incidental outcomes were found between vitamin D3 level and BMI as fibroids occur statistically significantly more often in patient having of BMI $\geq 25 \mathrm{~kg} / \mathrm{m}^{2}$. Also, menorrhagia and dysmenorrhea were the major complaints in $62.5 \%$ of cases followed by lowers abdominal pain and dyspareunia.

Conclusions: Our study reached significance in the inverse correlation between fibroids and vitamin D levels at the primary outcome level. Larger prospective longitudinal studies drawing on more number and eliminating confounding variables are needed.

Keywords: Uterine fibroid, Vitamin D3, Obesity, Leiomyoma

\section{INTRODUCTION}

The term uterine leiomyoma (UL) or uterine fibroids, are the most common benign tumor affecting the female reproductive system and primarily originates from uterine smooth muscles. ${ }^{1}$ The prevalence of UL has been estimated to range from approximately 5 to $69 \%$, varying according to the population. ${ }^{2}$ As uterine fibroids are mostly asymptomatic, their actual prevalence is underreported. UF are associated with significant morbidity in form of abnormal uterine bleeding, anaemia, pelvic pain, subfertility, and obstetric complications and causes financial burden to patient and affects their quality of life.

Pathogenesis of UFs appears to be multi-factorial. Apart from estrogen and progesterone, genetics has a role where MED12 mutations are the most prevalent, accounting for about $80 \%$ of UFs. Several factors cause genomic instability and thus convert normal myometrium stem cells to fibroid cells. This mechanism is suggested for vitamin D deficiency leading to fibroid through induction of DNA damage. 
Vitamin D plays a critical role in etiology of fibroid where by fibroids express lower levels of vitamin $\mathrm{D}$ receptors than adjacent healthy tissue. ${ }^{3}$ Additionally, vitamin $\mathrm{D}$ was reported to have immunologic properties via the vitamin $\mathrm{D}$ receptor (VDR) in reproductive tissues as well as antiinflammatory functions. ${ }^{4-6}$

It is a main regulator of calcium hemostasis and functional effects of vitamin D includes reduce cell proliferation, increased apoptosis, enhanced differentiation and regulation of biological processes like angiogenesis, extracellular matrix production and immune response. ${ }^{7}$ Vitamin D production in the body depends on various factors such as geographical location, environmental and individual characteristics (e.g., latitude, season, weather conditions, clothing), as well as the use of sunscreens and other cosmetics. Insufficient dietary intake and less exposure to solar radiation due to the majority of time indoors are believed to be the main reasons for vitamin D deficiency in white female population. ${ }^{8}$

Studies reveal a two to threefold higher incidence of uterine fibroids in African American females as compared to Caucasian females. ${ }^{5}$ Current available pharmacologic treatments for UFs include NSAIDS, mifepristone, selective progesterone receptor modulators and GnRh antagonist. Notably, none of these medical methods are fertility friendly and might require additional hormonal therapy if longer duration of treatment is required. Symptomatic uterine fibroids are treated with surgical methods, with both open and endoscopic options available like hysterectomy, myomectomy and hysteroscopic resection of fibroids. ${ }^{9}$

Thus, in long term treatment, vitamin D appears promising and cost effective non-hormonal method suitable for fertility desiring couples as well.

Recent studies have identified abnormal concentrations of vitamin $\mathrm{D}$ as important player in the etiology of uterine fibroids. Mean 25(OH) D3 serum levels are significantly lower in uterine fibroids- positive women as compared to uterine fibroid-negative controls. ${ }^{10}$

Also, studies have demonstrated that vitamin D significantly inhibited the growth of fibroids in-vitro, in vivo and other small trials. The biologically active form of vitamin $\mathrm{D}$ is $1,25(\mathrm{OH}) 2 \mathrm{D} 3$, which is found in almost every tissue in the body. Vitamin D3 binds to the nuclear vitamin $\mathrm{D}$ receptor (VDR), and then to a specific target DNA sequence known as the vitamin D response elements (VDREs). Uterine fibroids show reduced levels of vitamin $\mathrm{D}$ receptor (VDR) when compared with adjacent myometrium.

Therefore, it is possible that due to reduced levels of serum vitamin D3, there is reduced expression of VDR could be an important risk factor for uterine fibroids. ${ }^{11}$
The aim of the study was to evaluate whether deficiency of Vitamin D is associated with occurrence of uterine fibroid in reproductive stage Indian women.

\section{METHODS}

This cross-sectional observational study was conducted on 140 female patients (70 case group and 70 control group) aged between 18 to 50 years, presenting to the outdoor department of obstetrics and gynecology at Hindu Rao Hospital during a period of 1 year starting from July 2019 to June 2020 after Ethical clearance from the Institutional Ethics Committee and written informed consent was obtained from women who meet the inclusion criteria and who were willing to participate in the study. Women aged 18-50 years who are diagnosed as having uterine fibroids $(>1 \mathrm{~cm})$ by pelvic USG and with no uterine fibroids on pelvic ultrasonography as controls. Pregnant woman, women on hormonal treatment during last past 6-month, vitamin D supplementation in last 6 months, patient having history of prior myomectomy and other causes of abnormal uterine bleeding were excluded from the study.

For analysis of total vitamin D level, $2 \mathrm{ml}$ blood sample in plain vial on empty stomach was collected which were done in fully automated cobas 411 analyzer based on electrochemiluminescence technology. After testing for vitamin D levels, the WHO mandated criteria was applied to classify them in these 3 groups as (a) deficient: $<10$ $\mathrm{ng} / \mathrm{ml}$; (b) insufficient: $10-20 \mathrm{ng} / \mathrm{ml}$; (c) sufficient: $>20$ $\mathrm{ng} / \mathrm{ml} .{ }^{12}$ Data was collected, compiled, analyzed and valid conclusions were drawn.

The comparison of normally distributed continuous variables between the two groups was performed using student's t test and for more than two groups comparison done through ANOVA test. For all statistical tests, a p value less than 0.05 was taken to indicate a significant difference.

\section{RESULTS}

In this cross-sectional observational study done at Hindu Rao hospital to study the association between occurrence of fibroid in presence of hypovitaminosis D, we observed that there was no significant association between socioeconomic status and occurrence of fibroid ( $p$ value $=0.27$ ) (Table 1).

The mean vitamin $\mathrm{D}$ level in the women who attained menarche at or earlier than 12 years of age was $11.65 \pm 7.72$ $\mathrm{ng} / \mathrm{ml}$ and in women who had menarche more than 12 years was $14.35 \pm 9.34 \mathrm{ng} / \mathrm{ml}$.

There was no significant difference in mean vitamin D levels among two. However, the women who attained menarche at or earlier than 12 years of age had a lower vitamin D level as compared to those women who attained menarche after 12 years of age. 
Table 1: Socioeconomic status and fibroid.

\begin{tabular}{|c|c|c|c|c|}
\hline Socio-demographic cha & & $\begin{array}{l}\text { Cases }(\mathrm{N}=70) \\
\text { No }(\%)\end{array}$ & $\begin{array}{l}\text { Control }(\mathrm{N}=70) \\
\text { No }(\%)\end{array}$ & $P$ value \\
\hline \multirow{4}{*}{$\begin{array}{l}\text { Age group } \\
\text { (years) }\end{array}$} & $25-30$ & $8(11.4)$ & $8(11.4)$ & \multirow{4}{*}{0.85} \\
\hline & $31-35$ & $10(14.3)$ & $11(15.7)$ & \\
\hline & $36-40$ & $23(32.9)$ & $28(40.0)$ & \\
\hline & $41-45$ & $22(31.4)$ & $13(18.6)$ & \\
\hline \multirow{3}{*}{ Socio-economic status } & Upper middle & $10(14.3)$ & $9(12.8)$ & \multirow{3}{*}{0.27} \\
\hline & Lower middle & $41(58.6)$ & $36(51.4)$ & \\
\hline & Lower & $19(27.1)$ & $25(35.8)$ & \\
\hline
\end{tabular}

Menorrhagia and dysmenorrhea were the major complaints in $62.5 \%$ of cases followed by lowers abdominal pain and dyspareunia (Table 2). The mean value of BMI in cases was $25.8 \pm 3.77 \mathrm{~kg} / \mathrm{m}^{2}$ and in controls was $24.07 \pm 3.49 \mathrm{~kg} / \mathrm{m}^{2}$. There was significant association found between BMI and occurrence of fibroid in this study ( $\mathrm{p}$ value $=0.0277$ ). Subjects with $\mathrm{BMI} \geq 25 \mathrm{~kg} / \mathrm{m}^{2}$ (obese and overweight) had two times increased risk to develop fibroid as compared to those who had BMI $<25 \mathrm{~kg} / \mathrm{m}^{2}$ (normal and underweight (Table 3).

The mean value of vitamin $\mathrm{D}$ levels in cases was $12.81 \pm 8.56 \mathrm{ng} / \mathrm{ml}$ and in controls it was $19.83 \pm 9.21 \mathrm{ng} / \mathrm{ml}$. there was statistically significant difference ( $p$ value $<0.0001$ ) between the mean vitamin D levels among the case and control groups (Table 4).

Table 2: Distribution of study participants according to symptomatology.

\begin{tabular}{|llll|}
\hline Symptoms & Cases (\%) & Control (\%) & P value \\
\hline Menorrhagia & $44(62.85)$ & $39(55.71)$ & 0.3902 \\
\hline Dysmenorrhea & $44(62.85)$ & $43(61.43)$ & 0.8617 \\
\hline Lower abdominal pain & $38(54.28)$ & $35(50)$ & 0.5495 \\
\hline Dyspareunia & $6(8.57)$ & $5(7.14)$ & 0.7537 \\
\hline
\end{tabular}

Table 3: Distribution of participants according to BMI.

\begin{tabular}{|c|c|c|c|}
\hline BMI $\left(\mathrm{kg} / \mathrm{m}^{2}\right)$ & Cases (\%) & Control (\%) & Value \\
\hline Obese $(>30.0)$ & $7(10)$ & $4(5.71)$ & \multirow{4}{*}{$\begin{array}{l}\text { Odds ratio }=2.149 \\
\mathrm{P} \text { value }=0.0277\end{array}$} \\
\hline Oberweight (25-29.9) & $39(55.71)$ & $29(41.42)$ & \\
\hline Normal (18.5-24.9) & $20(28.57)$ & $32(45.7)$ & \\
\hline Underweight $(<18.5)$ & $4(5.71)$ & $5(7.14)$ & \\
\hline
\end{tabular}

Table 4: Distribution of vitamin D3 levels in cases and control.

\begin{tabular}{|lllll|}
\hline Serum vitamin D3 level $(\mathbf{n g} / \mathbf{m l})$ & Cases $(\%)$ & Control $(\%)$ & Odds ratio & P value \\
\hline Mean Vitamin D level & $12.81 \pm 8.56$ & $19.83 \pm 9.21$ & - & - \\
\hline Deficient $(<\mathbf{1 0} \mathbf{~ n g / m l})$ & $28(40)$ & $12(17.14)$ & $3.22(\mathrm{CI}=1.47$ to 7.059$)$ & 0.0035 \\
\hline Intermediate $\mathbf{( 1 0 - 2 0} \mathbf{~ n g / m l )}$ & $32(45.71)$ & $17(24.28)$ & $2.62(\mathrm{CI}=1.27$ to 5.398$)$ & 0.087 \\
\hline Sufficient $(>\mathbf{2 0} \mathbf{~ n g / m l )}$ & $10(4.28)$ & $41(58.57)$ & $0.11(\mathrm{CI}=0.519$ to 0.26$)$ & $<0.0001$ \\
\hline
\end{tabular}

\section{DISCUSSION}

This cross-sectional observational study was conducted on 140 female patients (70 case group and 70 control group) aged between 18 to 50 years, presenting to the outdoor department of obstetrics and gynecology at Hindu Rao Hospital during a period of 1 year starting from July 2019 to June 2020.

This study was conducted with the primary focuss to estimate and compare the vitamin D level in patients with fibroid uterus and patients without fibroid uterus on pelvic ultrasound. Secondary aim was to study the association of vitamin D level with leiomyoma uterus and to study vitamin D deficiency as a risk factor for leiomyoma uterus.

In our study the mean age distribution among cases was $39.11 \pm 6.05$ years and controls was 38.84 \pm 5.75 years. There was no statistically significant difference was observed in the mean age of control and study groups ( $p$ value $=0.85$ ), so women in both the groups were of comparable age. Similarly, Ajmani et al found that the mean age among the cases was $36.79 \pm 8.97$ years and controls was $38.60 \pm 7.78$ years. ${ }^{13}$ In the study by Singh et al mean age of the cases was $41.79 \pm 4.91$ years and controls was $42.18 \pm 5.37$ years $(\mathrm{p}$ value $=0.649) .{ }^{14}$ Oskovi et al 
showed mean age of the cases was $38.25 \pm 4.88$ years and controls was $39.84 \pm 3.99$ years $(\mathrm{p}$ value $=0.09) .{ }^{15}$

In our study mean BMI among cases and controls was $25.8 \pm 3.77 \mathrm{~kg} / \mathrm{m}^{2}$ and $24.07 \pm 3.49 \mathrm{~kg} / \mathrm{m}^{2}$ respectively. Obese and overweight patients had twice the risk of developing fibroid as compared normal and underweight patients. There was significant association found between BMI and occurrence of fibroid in this study ( $p$ value $=0.0277$ and odds ratio=2.15). So, obesity could be considered a risk factor for uterine fibroids.

Similarly, in the study by Singh et al mean BMI in case and control group was $27.18 \pm 3.68 \mathrm{~kg} / \mathrm{m}^{2}$ and $25.92 \pm 3.51$ $\mathrm{kg} / \mathrm{m}^{2}$ respectively and significant association was found between BMI and occurrence of fibroid $(\mathrm{p}$ value $=0.037) .{ }^{14}$

Similar outcome was found by Ciebierain et al in which mean BMI in case and control group was 26.67 \pm 5.01 $\mathrm{kg} / \mathrm{m}^{2}$ and $24.03 \pm 4.47 \mathrm{~kg} / \mathrm{m}^{2}$ respectively and significant association was found between BMI and occurrence of fibroid $(\mathrm{p}$ value $=0.0002){ }^{4}$

Previously, Paffoni et al found that mean BMI in case and control group was $22.9 \pm 3.6 \mathrm{~kg} / \mathrm{m}^{2}$ and $22.1 \pm 3.3 \mathrm{~kg} / \mathrm{m}^{2}$ respectively and significant association was found between BMI and occurrence of fibroid $(\mathrm{p}$ value $=0.04) .{ }^{16}$

In contrast Ajmani et al found that mean BMI in case and control group was $26.2 \pm 4.68 \mathrm{~kg} / \mathrm{m}^{2}$ and $24.08 \pm 11.6 \mathrm{~kg} / \mathrm{m}^{2}$ respectively. There was no significant association found between BMI and occurrence of fibroid $(\mathrm{p}$ value $=0.145) .{ }^{13}$

In our study the mean value of vitamin $D$ levels in cases was $12.81 \pm 8.56 \mathrm{ng} / \mathrm{ml}$ and in controls it was $19.83 \pm 9.21$ $\mathrm{ng} / \mathrm{ml}$ with $\mathrm{p}$ value $<0.0001$. On analysis of vitamin $\mathrm{D}$ levels, $40 \%$ of women with fibroid and $17.14 \%$ of women without fibroid were associated with severe deficiency of vitamin $\mathrm{D}(<10 \mathrm{ng} / \mathrm{dl})$. Moreover, only $14.285 \%$ of women with fibroid as compared to $58.57 \%$ of women without fibroid had sufficient vitamin D level (>20 ng/dl). So, risk of having fibroid in vitamin D deficient women was 3.22 times higher $(\mathrm{OR}=3.22)$ and in vitamin $\mathrm{D}$ insufficient women was 2.62 times higher $(\mathrm{OR}=2.62)$.

Deficient or insufficient levels of Vitamin D are significant risk factor associated with occurrence of fibroid as compared to controls. In 2013 Paffoni et al conducted a cross sectional study which included 128 women as cases and 256 as controls. They found that $15 \%$ of women with fibroid had severe deficiency and sufficient vitamin D level was found in $37 \%$ of cases as compared to $45 \%$ in controls with mean value of vitamin D levels was $18 \pm 7.7$ $\mathrm{ng} / \mathrm{ml}$ in cases and the mean value of vitamin D levels was $20.8 \pm 11.1 \mathrm{ng} / \mathrm{ml}$ in controls leiomyomas with an odds ratio of 2.2. This study is highly congruent with the present study even with the much greater sample size. ${ }^{16}$

Similarly, in a study by Ajmani et al the mean vitamin D level in cases and control was $12.58 \pm 4.09 \mathrm{ng} / \mathrm{ml}$ and
$18.99 \pm 5.72 \mathrm{ng} / \mathrm{ml}$ respectively, with $\mathrm{p}$ value $<0.001$. They found that low levels of vitamin $\mathrm{D}$ were associated with a higher risk of fibroid. ${ }^{13}$

In similar analysis found by Singh et al in 2018, they found mean serum concentration of vitamin D3 was significantly lower in women with uterine fibroids compared to controls $(10.81 \pm 6.18$ vs $22.91 \pm 16.18, \mathrm{p}<0.0001) .{ }^{14}$

In the prospective observational cross-sectional study by Oskovi et al, mean level of vitamin $\mathrm{D}$ in cases was $6.54 \pm 4.66 \mathrm{ng} / \mathrm{ml}$ and in controls was $8.18 \pm 5.16 \mathrm{ng} / \mathrm{ml}$ with $\mathrm{p}$ value 0.009 . $^{15}$

Large cohort studies that have monitored vitamin D3 showed that those who are low (or high) at baseline tend to remain low (or high) during multiyear follow-up. ${ }^{17}$ The best way to fulfill this aim would be a prospective longlasting cohort study with serial monitoring of vitamin D status.

Longitudinal studies including larger number of participants with controls would confirm/refute this association.

\section{CONCLUSION}

This study signifies the inverse correlation between fibroids and vitamin D levels at the primary outcome level. However, as this study was time constrained, it was limited in drawing this as incontrovertible evidence. Larger prospective longitudinal studies drawing on more number and eliminating confounding variables are needed. The present study helps in the conformation of critical role of vitamin $\mathrm{D}$ deficiency among fibroid cases and may open new therapeutic scenarios. Vitamin D supplementation would have the potentiality to become a simple and economic means to prevent fibroids development or growth.

\section{Funding: No funding sources}

Conflict of interest: None declared

Ethical approval: The study was approved by the Institutional Ethics Committee

\section{REFERENCES}

1. Lethaby A, Vollenhoven B. Fibroids (uterine myomatosis, leiomyomas). BMJ Clin Evid. 2011;2011:0814.

2. Ishikawa H, Ishi K, Serna VA, Kakazu R, Bulun SE, Kurita T. Progesterone is essential for maintenance and growth of uterine leiomyoma. Endocrinology. 2010;151(6):2433-42.

3. Ali M, Shahin SM, Sabri NA, Hendy A, Yang Q. Hypovitaminosis D exacerbates the DNA damage load in human uterine fibroids, which is ameliorated by vitamin D3 treatment. Acta Pharmacol Sin. 2019;40(7):957-70. 
4. Ciebiera M, Wlodarczyk M, Zgliczynska M, Lukaszuk K, Meczekalski B, Kobierzycki C, et al. The role of tumor necrosis factor alpha in the biology of uterine fibroids and the related symptoms. Int J Mol Sci. 2018;19(12):3869

5. Brakta S, Diamond JS, Hendy A, Diamond MP, Halder SK. Role of vitamin D in uterine fibroid biology. Fertil Steril. 2015;104(3):698-706.

6. Elhusseini H, Elkafas H, Abdelaziz M, Halder S, Atabiekov I, Eziba N, et al. Diet-induced vitamin D deficiency triggers inflammation and DNA damage profile in murine myometrium. Int J Women's Health. 2018;10:503-14.

7. Sabry M, Hendy A. Innovative oral treatments of uterine leiomyoma. Obstet Gynecol Int. 2012;943635.

8. Nair R, Maseeh A. Vitamin D: The "sunshine" vitamin. J Pharmacol Pharmacother. 2012;3(2):11826.

9. Kalampokas T, Kamath M, Boutas I, Kalampokas E. Ulipristal acetate for uterine fibroids: a systematic review and meta-analysis. Gynecol Endocrinol. 2016;32(2):91-6.

10. Blauer M, Rovio PH, Ylikomi T, Heinonen PK. Vitamin D inhibits myometrial and leiomyoma cell proliferation in vitro. Fertil Steril. 2009;91(5):191925.

11. Hendy A, Diamond MP, Sohemy A, Halder SK. 1,25dihydroxyvitamin D3 regulates expression of sex steroid receptors in human uterine fibroid cells. J Clin Endocrinol Metab. 2015;100(4):572-82.
12. WHO Scientific Group on the Prevention and Management of Osteoporosis. Prevention and management of osteoporosis: report of a WHO scientific group. Geneva: Switzerland; WHO; 2003.

13. Ajmani SN, Sarbhai V, Singh S, Ajmani A, Pant L. To establish the association of vitamin D levels with leiomyoma and its role as a risk factor for development of leiomyoma uterus. Indian Obstet Gynaecol. 2018;8(4):46-9.

14. Singh V, Barik A, Imam N. Vitamin D3 Level in Women with Uterine Fibroid: An Observational Study in Eastern Indian Population. J Obstet Gynaecol India. 2019;69(2):161-5.

15. Oskovi KZA, Taşçi Y, Topçu HO, Erkaya S. 25Hydroxy vitamin D levels in premenopausal Turkish women with uterine leiomyoma. Gynecol Endocrinol. 2018;34(3):261-4.

16. Paffoni A, Somigliana E, Vigano P, Benaglia L, Cardellicchio L, Pagliardini L, et al. Vitamin D status in women with uterine leiomyomas. J Clin Endocrinol Metab. 2013;98(8):1374-8.

17. Baird DD, Hill MC, Schectman JM, Hollis BW. Vitamin $d$ and the risk of uterine fibroids. Epidemiology. 2013;24(3):447-53.

Cite this article as: Choudhary S, Shukla M, Joshi R. Study of association between hypovitminosis D and fibroid uterus. Int J Reprod Contracept Obstet Gynecol 2021;10:2432-36. 